Southeast Asian Review of English, 52.1(2014/2015): 143-166.

\title{
Africa or Africanness in Derek Walcott's Omeros $^{1}$
}

\section{Haleh Zargarzadeh}

"Return to Africa" is a pervasive theme in Caribbean literature and celebrated Nobel Prize winning poet and playwright from St. Lucia, Derek Walcott, also engages with this theme. However, in contrast to Pan-Africanists and other proponents of Négritude, Walcott does not idealize or romanticize Africa as home for New World inhabitants. This paper examines Walcott's Omeros (1990) to explore the ways in which this epic poem portrays the complexities of "return to Africa" for New World inhabitants. Because the Caribbean has withstood the violence of its past, the attempt to return to the past and to retrieve it may cripple the mind. This paralysis is investigated in Achille's hallucinatory katabatic nostos to Africa. In this journey, as will be shown, Walcott demonstrates the estrangement and the alienating sense of Africa for the New World inhabitants. However, as Walcott argues, if due to the ruptures of history Africa is lost for Afro-Caribbeans, Africanness can still be gained by accumulating its cultural sediments. Moreover, through Achille's journey, Walcott proposes that the New World inhabitants should appreciate the prospects of the present - here and now - rather than being lost in the mirages of the past.

\section{Introduction}

Initiated by francophone Afro-Caribbean intellectuals in Paris in the 1930s i.e. Aimé Césaire (from Martinique), Sédar Senghor (from Senegal), and Léon-Gontran Damas (from Guiana), Négritude celebrates Africa as home for Afro-descent people (François ix) and 
Southeast Asian Review of English, 52.1(2014/2015): 143-166.

determines identity in the parameters of roots. However, Derek Walcott, similar to other Caribbean intellectuals such as Édouard Glissant and Wole Soyinka, distances himself from Négritude and its ideologies. ${ }^{2}$ To Walcott Négritude is monolithic, marginalizing, nostalgic, and unreal ("Necessity of Négritude" 20-23). Walcott also argues that romanticizing Africa as home for Afro-descent people is not viable as black people in the West have experienced religion, language, and culture very differently from the original African heritage (20). Walcott quotes Eliot, “'you gotta use words,' and the words he uses, to stretch the points, to absurdity are the white man's words'. So, in the Western World, are his God, his dress, his machinery, his food. And, of course, his literature" (20). Hence, Walcott contends that such a spatial and temporal fusion is not natural; it is forced (20).

In spite of Walcott's negative stance toward Négritude, some scholars contend that he engaged with this ideology more as he developed his own literary voice. Rei Terada argues that "Walcott shows more empathy with Africa ... as his career develops" (26). In support of Terada's argument, Shane Graham also contends that “Achille's dream-journey back to Africa lacks the implicit scorn that characterizes many statements the younger Walcott made about Afrocentrism movement" (109). In Dream on a Monkey Mountain (1967), Makak, Walcott's protagonist, travels to Africa. Twenty three years later in Omeros, Walcott similarly sends Achille to Africa in a hallucinatory journey. There are also other omeric characters who engage with Africa in one way or another: Sybil and obeah woman Ma Kilman, starts on a religious quest to find an African herb to cure Philoctete's ancestral wound (235-48). Even though Walcott evokes Africa in Omeros and 
Southeast Asian Review of English, 52.1(2014/2015): 143-166.

through the figure of Ma Kilman associates Africa with healing qualities, it is my contention that this engagement is not to support the Back-to-Africa campaign. Through Achille's dream vision, Walcott intends to highlight Africa's distance from the lived reality of life in the Caribbean. In "What the Twilight Says," Walcott argues that Africa is "no longer home" for us (38). ${ }^{3}$ To Walcott, African roots are to be recognized not to be fetishized (Baer 18).

In what follows I will focus on Achille's journey to show the ways in which Walcott depicts the difficulties of "return[ing] to Africa." Through the figure of Achille, I will also clarify that if Africa is difficult to reach, it can be grasped in other ways.

St. Lucia, a beautiful island in the Caribbean, obtained its independence in 1979. Nevertheless, the dynamics of neo-colonialism in the form of exploitative tourism hover very strongly in the backstage of the story and affect the life of Walcott's simple and poor fishermen in the village in one way or another. ${ }^{4}$ In Omeros, Walcott draws a very clear picture of tourism and its negative consequences on the lives of the villagers; some characters attune themselves with the resultant new rhythm of life while others alienate themselves from mainstream community. Achille and Hector are both fishermen although in the course of the story, Hector sells his canoe for a passenger van to transport tourists in the village but Achille remains faithful to the sea till the end. Though the sea bonds Achille and Hector together, there is "bad blood" between them as they compete for the love of Helen, a headstrong and beautiful local girl who works as a waitress in the island's hotels. Unlike Hector and Helen, Achille cannot assimilate himself to the new pattern of life generated by the presence of tourists on the island. 
Southeast Asian Review of English, 52.1(2014/2015): 143-166.

To illustrate the corruption of tourism and the deterioration of the simple village life, Walcott describes a festival—a Saturday night block fête (109-115) — in which tourists and villagers mingle. On Saturday nights, Gros Îlet prepares for the fête with "barbecues of chicken and conch," "Frenetic DJs," "domino games," and "Tourists, in seraphic white" (109-10). The intruding presence of tourists separates Achille from the villagers and village activities. He does not go for the festival but it sickens him when he indignantly watches Helen from a distance who walks, dances and whores herself among the tourists. ${ }^{5}$ First, he decides to share his sense of loneliness with Seven Seas whom he envies as he cannot see the corruption of innocence in the island but then he goes towards the sea and watches Helen who sells herself painlessly like the island to the indifference of the village (111). Achille's pain intensifies as DJs scream: "WE MOVIN', MAN! WE MOVIN'!” (112) but Achille broods over this deteriorating move as he sees flour changing into cocaine and daughters to whores (112). The future is gloomy; this is what Achille ponders as he sees Helen like a bright meteor fading unknown in the village. When Helen returns home after blocko, Achille throws his lance of resentment at her, castigating her: "[m]ore men plough that body than canoe plough the sea" (115). Helen remains silent that night but soon after leaves him for Hector.

Even though the villagers are mostly of African-descent, Africa is forgotten. Instead, people accustom themselves with the rhythms of life in the New World. But Achille is different. There is a vague sense of void which distances him from such activities. His sense of attachment to the sea is greater than that to the land. He has a canoe and still works with the sea even though the young have lost their interest in canoes which 
Southeast Asian Review of English, 52.1(2014/2015): 143-166.

"was longtime shit. Once it came from Africa" (112). A day after the block fête, Achille goes fishing, while lost in thought about Helen. But this fishing trip is different from everyday fishing expeditions as his dream-journey to Africa happens in this sequence of the story. In this hallucinatory journey, Achille's soul flies to Africa in order to redeem his ancestral birthright and to glue together the broken fragments of the lost history of Africa, an excavation which, as Walcott shows, will assist him in healing his amnesia of Africa and Africanness. ${ }^{6}$ Before analyzing Achille's journey to Africa, I will first discuss the scholarly debates regarding the kind of journey he takes to Africa.

\section{Nostos or Katabasis?}

Scholars have described Achille's journey "Back to Africa" in various ways. Some have considered it as nostos while for others it falls within the paradigm of katabasis. Katabasis is an epic motif. In Edith Hall and Justine McConnell's definition, katabasis,

has featured in, among others, Virgil and Dante, Homer and the Epic of Gilgamesh, as well as in the works of Freud and Marx. During a katabasis, the traveller undergoes a series of trials through which he is metaphorically destroyed and reborn anew, often with new strength or knowledge. The Odyssey's katabasis sees the hero descend to the underworld, ostensibly to question Teiresias about his route home. As he meets his mother there, as well as some famous warriors who had died at Troy, the episode emphasizes a reassessment of the Iliadic code, particularly seen in Achilles' volte-face regarding the decisions 
Southeast Asian Review of English, 52.1(2014/2015): 143-166.

he should have made. The sequence renews Odysseus' confidence, links him once more to his past, and provides him with advice for the future. (354)

McConnell, like Gregson Davis, Lorna Hardwick, and Rachel D. Friedman, does not take Achille's hallucinatory African voyage as nostos. ${ }^{7}$ To her, this journey is "katabasis," a "nekuian katabasis," which is a rite that guarantees Achille's retour to his "true home" in St. Lucia (120). Nekyia / Nekuia is an ancient Greek rite for a journey to the underworld in search of light. In Nekyia and katabasis, the traveler has the chance to negotiate with the dead but the actual journey happens only in katabasis. After this journey, as McConnell argues, Achille develops a deeper understanding of his situation in the New World as an individual who envisions the world with a transformed perception (120-21). In her contention, McConnell brings up Walcott's own notion that "return to Africa" is an inferior idea given that the West Indies, by itself, is a reality, though a "mosaic" model which must be explored (Rodman 240).

I have no quarrel with McConnell's reasoning regarding Walcott's denounciation of Négritude. Despite her argument, I, however, want to suggest that Achille's journey to Africa is better viewed as a nostos not a katabasis. This idea is in line with Terada and Peter Burian's view that Achille's journey is nostos $;{ }^{8}$ but my argument, different from them, is that the journey is a "katabatic nostos," a concept I have borrowed from Davis. In “"Homecomings without Home," Davis analyzes the theme of nostos in Césaire's Cahier d' un retour au pays natal (1939/47) and Walcott's "Homecoming: Anse La Raye" (1969). This classical scholar reads the motif of nostos within the framework of katabasis, 
Southeast Asian Review of English, 52.1(2014/2015): 143-166.

reasoning that the retour of the poet-narrator to his homeland is similar to nostos as most Caribbean writers are exile writes. However, since this return is to a postcolonial scenario, it is katabatic. It is like a visit to the underworld, to the domain of the dead where even the last residue of the indigenous culture and ancestral heritage are dying, defunct or gone (196).

Katabasis is a necessary stage in an epic hero's maturation but when an epic hero visits the underworld, as in traditional heroic poems, from the outset he knows that it is a temporary stop where he will be told about the future course of events and afterwards he is to resume his corporeal life but with a renewed perception. ${ }^{9}$ The realm of the dead cannot be home for the visiting epic hero; in Achille's case Africa could be — and indeed is—his true homeland but due to the violent intervention of colonialism, enslavement, and Middle Passage, he has been deprived of his birthright. By taking Achille's journey as katabatic nostos, another important issue is also illumined. As nostos, this journey practically demonstrates the ways in which Walcott discards Africa as home for Afro-Caribbeans. As katabasis, it demonstrates the unreachability of Africa - that it is as dead a realm for AfroCaribbeans as it is for Achille. Having developed such an assumption, I shall now proceed to examine the ways in which this Afro-Caribbean character experiences his ancestral homeland.

A sea-swift guides Achille to Africa by "widening the joy that had vanished from his work" (125). Her presence at first fills Achille with joy and bliss but afterwards Achille realizes that the song of this restless bird is intonated with sorrow. Walcott sends Achille home, to Africa, to an unknown past and ambivalently to an unfamiliar place, a Middle 
Southeast Asian Review of English, 52.1(2014/2015): 143-166.

Passage from the New World to the Old. In this epic within an epic, as in traditional heroic formulae, Achille recalls a catalogue of names: the names of his African brothers who did not survive the crossing (127-28). This recollection may sound abrupt but the sea revives Achille's mindfulness of the past as the sea is a repository of history and ancestral memory, a memory which Glissant calls "unconscious memory" (Poetics of Relation 7). Achille then visualizes the African slaves being disgorged from each swell. The ancestral memory and the violence of the history restored in Achille's mind sicken him. ${ }^{10}$ As the Caribbean has suffered a violent past, Walcott, in Omeros as well as in his essays, repudiates a simple revival of the past. In his Nobel Lecture Walcott proclaims: "[w]e make too much of that long groan which underlines the past.... The sigh of History rises over ruins, not over landscapes, and in the Antilles there are few ruins to sigh over, apart from the ruins of sugar estates and abandoned forts" ("The Antilles, Fragments of Epic Memory" 262). Walcott argues that the Caribbean people should observe the natural scenery of the region as refreshing and energizing elements in order to forget the atrocities of the past and move beyond them.

The recollection of the past, of history, and his torn lineage to Africa affects Achille's mind. Achille, like Shabine in Walcott's "The Schooner Flight" and Odysseus in The Odyssey: A Stage Version, is both a sea-farer and a hi/story teller who recounts the history of Africa and his unforgettable tribal memory; a history buried in the Atlantic Ocean along with the countless corpses at the bottom of the cold sea. His journey begins when the ghost of his father appears to awaken his consciousness to his lost identity, roots, and origin (130). His memories take him into the distant past, to three hundred years ago. 
Southeast Asian Review of English, 52.1(2014/2015): 143-166.

Then he tries to recall and recite the names of the river god and the tree god but he could not. This oblivion makes him very ashamed. He then gradually remembers this "sunburnt river" in Congo (135). He sees some naked Africans who silently stare at his canoe. Then the prow stops, finding a stake: Achille is moved by the scenery, by his presence in his ancestral land, and by seeing his fellow Africans. He weeps so hard, his tears flow like a "rivulet" (135). At this sequence, the poet-narrator interrupts the narrative to express his concern for Achille. ${ }^{11}$

Evidently Achille's journey across time and space has its own forebodings as he is shown to be at the neither-nor state of happiness and unhappiness in his homeland. As the story advances, Achille's homecoming proves to be "unhomely," a concept which Freud outlines as "unheimlich" and Homi Bhabha reappropriates as the "unhomely." In his paper “The Uncanny" (1919), Freud explicates the dictionary meaning of un/heimlich — a concept associated with feelings which deal with "subdued emotional impulses" (219). Among the different variations of the uncanny specified by Freud, Bhabha builds his concept of "unhomely" on the following formulation: "[u]nheimlich is the name for everything that ought to have remained [...] secret and hidden but has come to light" (224) (italics original). Freud's version of this concept mainly emphasizes the repressed and restrained memories, anxieties, and emotions experienced in the past on the personal or individual level. Bhabha expands the referential frame of this psychological concept to encompass postcolonial experiences: traumas experienced in the course of history not only individually but collectively. Forced migrations, displacements, dispossession, diaspora, and exile are the heralds of the colonial expansion policies endured racially. When the memories of the 
Southeast Asian Review of English, 52.1(2014/2015): 143-166.

past resurface, they stir an unhomely moment for the individual. In what follows I will examine the ways in which Walcott exposes Achille to some incidents in Africa in order to highlight the tormenting effects of the retrieval of the past.

\section{Paralysis of History}

In Africa, Achille witnesses a slave raid when suddenly shafts rain on the terrified huts and the raiders attack and destroy everything, even yams in the gardens. When the raid is over, the raiders take fifteen slaves for the slavers. Achille is motionless in the middle, unable to move. Then he goes up a ridge and sees his fellow brothers chained to each other like ants. When the line disappears, he returns to the dusty silent village. There are only arrow shafts lying around the houses. He opens a door and finds "Seven Seas foaming with grief. He must / be deaf as well as blind" (145). Seven Seas is counting the list of battles to the river. Achille is grieved because "[h]e foresaw their future. He knew nothing could change it" (146). He was lost in the thought of the chained ants reaching up to the sea or going up piles of coal into the "dark hold" (146).

In this scene, Walcott presents Achille as quite impotent and helpless: "[he] could not hide / or fight. He stood in their centre, with useless arms" (144). Here, Achille is in the interstices of his Greek namesake and his Caribbean self; he can neither act courageously as Homer's Achilles nor as Walcott's fisherman. While some scholars have associated these two characters with each other, Walcott's fisherman has only inherited his Greek

namesake's vulnerable heels not his courage. ${ }^{12}$ Even though a fisherman, he could defend his tribesmen with his weapon, an oar, but as he is a ghost in Africa, he cannot act. He is a 
Southeast Asian Review of English, 52.1(2014/2015): 143-166.

mere witness. Though a ghost, paradoxically, he will resume his earthly life again. Following Bhabha's definition, Achille is somewhere between life and death and it is exactly this interstice of action / non-action which makes him uncomfortable in Africa. But he is outraged and looks for chances to retaliate. He finds an oar, runs to the pier and sees slave raiders. He violently kills one of the slavers, vainly trying to help save his people. ${ }^{13}$ Full of hatred, he hammers his brain so hard that his skull comes out. Then he leaves the crime scene like an ocelot or a leopard. At this moment something comes to Achille's mind, he thinks of saving his African brothers. If he does, he could change history. Lost in thoughts of vengeance, "a cord / of thorned vine looped his tendon, encircling the heel / with its own piercing chain. He fell hard" transformed to the archer he had brained out (148).

Achille fails in rescuing his enslaved brothers yet this failure does not indicate his impotence in real life. As a fisherman, he is expected to fight with the sea and as Walcott argues confronting "a natural element is more challenging than an army. You can perhaps face an army. You cannot face a hurricane" ("Reflections on 'Omeros"” 244). By portraying Achille helpless in the midst of the raid, Walcott aims to emphasize that no one can change the course of past events. Consciousness of the past, as it is tormenting, could also leave a deadening effect on the mind of the individual. That is why Walcott is against romanticizing the past. Maeve Tynan has also noted that "Walcott argues here as elsewhere that the past must be accepted-it is time to move on (241). In his Nobel lecture, Walcott describes the footmark of historical wounds on the Caribbean nature: 
Southeast Asian Review of English, 52.1(2014/2015): 143-166.

It is not that History is obliterated by this sunrise. It is there in Antillean geography, in the vegetation itself. The sea sighs with the drowned from the Middle Passage, the butchery of its aborigines, Carib and Aruac and Taino, bleeds in the scarlet of the immortelle, and even the actions of surf on sand cannot erase the African memory, or the lances of cane as a green prison where indentured Asians, the ancestors of Felicity, are still serving time. (“The Antilles, Fragments of Epic Memory” 266)

Walcott is quite aware of the scars of history that have wounded the mind and soul of the Caribbean people. Another Life, his autobiographical poem first published in 1973 and reprinted in an annotated version by Edward Baugh and Colbert Nepaulsingh, also deals with the negative dimensions of literature which celebrates the wounds of history:

those who peel, from their own leprous flesh, their names, who chafe and nurture the scars of rusted chains, like primates favouring scabs, those who charge tickets for another free ride on the middle passage,

Their music comes from the rattle of coral bones, their eyes like worms drill into parchment, they measure each other's sores to boast who has suffered most, (Baugh and Nepaulsingh 127-28) 
Achille, victim of slavery and the Middle Passage, has been paralyzed and dumbed down as history unreels before his stupefied eyes like a live movie: slave raid, enslavement, the tragedy of the Middle Passage, drowned slaves, rusted balls and chains. All these painful scenes have created an uncanny sensation which leads to Achille's estrangement from other Africans: "Achille, among those voluble leaves, his people, / estranged from their chattering, withdrew in discontent" (140). Achille gradually understands that his "proper place / lay in unsettlement" (140), that Africa cannot be his true home. This intensifies his disillusionment with Africa. If his ancestral homeland, Africa, is not his home, where is his home? Where else could he set anchor? As the story unfolds, however, Walcott plants seeds of hope and possibilities. Lost in disappointment, one day to his great astonishment, he comes across a surprising scene which looks familiar to him. He sees the Boxing Day ceremony ${ }^{14}$ which was conducted in the same way as in the Caribbean.

Achille saw the same dances

that the mitred warriors did with their bam boo stick as they scuttered around him, lifting, dipping their lances like divining rods turning the earth to music.

the same chac-chac and ra-ra, the drumming the same, and the chant of the seed-eyed prophet to the same response from the blurring ankles. The same, the same. (143) 
Southeast Asian Review of English, 52.1(2014/2015): 143-166.

By this similarity, Walcott suggests that if Africa is lost, Africanness could still be preserved in the New World. This likeness indicates a sense of connectivity between the old continent and the New World. Hence, it can be inferred that there could be more connective links between Africa and the Caribbean; there is still hope to reach Africa in other ways. In his visionary journey, Achille tries to retrieve his ancestral values by listening to griot songs or by taking undersea exploratory voyages. However, by these recuperations, he does not intend to romanticize or idealize Africa. The recovery of the past would equip him for a better life in the New World.

\section{Retrieving the Past}

In spite of his disenchantment with Africa, Walcott furnishes the story with rays of hope and possibilities by assigning Achille with a mission to accumulate long buried sediments of African values. As Fanon argues colonizers were not content with only turning the minds of the colonized into tabulae rasae: "[i]n a perverted logic, it turns to the past of oppressed people, and distorts, disfigures and destroys it" (210). Achille is one of those individuals Fanon describes. Emptied of his past, Walcott sends him on a recuperational mission to reclaim and to re-collect some long-lost rituals. In Africa, he learns to chew kola nut, drink palm wine, listen to the tribal hi/stories, and recite the names of the deities (139-40).

These are African rituals, Achille's ancestral lore, which African people should supposedly know as they lie buried in the Atlantic. Besides these rituals, Walcott appoints Achille with two undersea voyages in Africa: in the first one Achille, like a walking fish, walks on the seabed for three hundred years and finds "huge cemeteries / of bones and the 
Southeast Asian Review of English, 52.1(2014/2015): 143-166.

huge crossbows of the rusted anchors" (142). The undersea journey opens pages of African history before Achille's eyes, the tragic story of the Middle Passage, a history saturated with violence, greed, and loss. On another occasion, Achille appears from the seabed like an astronaut weightlessly floating in the water as if confused. This time, he pages the book of world history from the last three centuries up to the present. There he is told of torn treaties, governments' rise and fall, kings' ascent to and descent from the throne, Toussaint L'Ouverture's death in the Pyrenees, Queen Victoria's reign over vast empires, Darwin's theory of evolution, indentured workers of Fatel Rozack, and many other sea battles. By excavating history, Achille tries to re-construct his African identity as historical lore, in James McCorkle's words, the building block of "self-knowledge"(5). Apart from sea journeys, Achille listens to the griot's prophetic song of sorrow:

The griot crouched there. Warm ashes made his skull white over eyes sore as embers, over a skin charred as coal, the core of his toothless mouth, groaning to the firelight,

was like a felled cedar's whose sorrow surrounds its bole. One hand clawed the pile of ashes, the other fist thudded on the drum of his chest, the ribs were like a caved-in canoe

that rots for years under the changing leaves of an almond, (146-47) 
Southeast Asian Review of English, 52.1(2014/2015): 143-166.

McConnell contends that the griot's role in the community is not just for entertainment but also, as in the Odyssey, to preserve "history for the present, in order that it may be learned from, and the communal identity of people may be understood and reaffirmed" (128). The griot is burning with sorrow; he is clawing the ashes. He tells Achille the story of their slavery: they were taken from Bight of Benin and from the margin of Guinea, chained together, taken to slave ships and scorched on the deck, "our tubers withered in no time" (149). However, as griot reveals, it is not their tragic destiny which torments them. They suffer more when they see that the younger generations like Helen, Hector and Lawrence of St. Lucia have forgotten their ancestors' pains and work for the tourists (23). The griot then asks Achille to "remember [them] to the black waiter bringing the bill" to the tourists (149). In St. Lucia, a touristic destination advertised in brochures, black people work for the white / tourists; Walcott takes this as a kind of servitude. In fact the griot assigns Achille with a kind of responsibility which, in itself, is one of the features of katabasis discussed earlier. Davis analyses the ramifications of katabasis in his article among which the following arguments most reverberate in Achille's African journey. This classical scholar contends that katabasis matures the epic hero by deepening his understanding of self and the community in which he lives. This deepened awareness assigns a sense of collective responsibility on the epic hero's shoulders in enlightening others (195). This is how Achille's katabatic nostos to Africa ends by widening his sense of the individual and communal in many respects. Achille not only attempts to maintain his own sense of Africanness when he returns to his village but he also tries to enlighten others of their racial lineage and heritage. This is quite evident when he explains the significance 
Southeast Asian Review of English, 52.1(2014/2015): 143-166.

of the Boxing Day festival to Helen (275) or when he decides to give an African name to Helen's child (318). This is how Achille, according to Stuart Hall, reaches Africa "but by another route" (232).

Unlike proponents of Négritude, Derek Walcott sends omeric Achille to Africa not to stay but to redeem his ancestral birthright in order to heal his amnesia of Africa and Africanness. Through this journey, Walcott intimates that Africa cannot be home for AfroCaribbeans while Africanness can still be preserved even in other lands. This is how Achille comes to realize that Africa has not been totally lost as certain rituals are still conducted in the same way in the Caribbean. Hence, Achille is like Makak in Dream on a Monkey Mountain, who goes to Africa not to stay but to restore "hereditary seeds that survived the Atlantic crossing, seeds that are rooted in Caribbean soil" (Hamner 75). This is Achille's communal responsibility as a katabatic homecomer to try to keep Africa's longforgotten rituals alive. Through Achille's trajectory of katabatic nostos to his homeland, Walcott illustrates that reviving the history of the Caribbean may paralyze the individual as this archipelago has suffered a violent past. Hence, as Walcott argues, the New World inhabitant should perceive the world in a new light and should appreciate the here and now. 
Southeast Asian Review of English, 52.1(2014/2015): 143-166.

\section{Works Cited}

Baer, William (ed.). Conversations with Derek Walcott. Jackson, Mississippi: University Press of Mississippi, 1996. Print.

Baugh, Edward and Colbert Nepaulsingh. Derek Walcott: Another Life, Fully Annotated. London: Lynne Rienner Publishers, 2004. Print.

Bhabha, Homi. The Location of Culture. second ed: Routledge Classics, 2004. Print.

Braziel, Jana Evans. “Caribbean Genesis: Language, Gardens, Worlds (Jamaica Kincaid, Derek Walcott, Édouard Glissant)." Caribbean Literature and the Environment: Between Nature and Culture. Ed. Elizabeth M. Deloughrey, Renée K. Gosson and George B. Handley: Charlottesville: University of Virginia Press, 2005. 110-27. Print.

Burian, Peter. “'All That Greek Manure under the Green Bananas': Derek Walcott's Odyssey'.” South Atlantic Quarterly 96.2 (1997): 359-77. Print.

Burnett, Paula. Derek Walcott: Politics and Poetics. University Press of Florida, 2000. Print.

Carrigan, Anthony. "Postcolonial Tourism, Island Specificity, and Literary Representation: Observations on Derek Walcott's Omeros." Space and Culture (2010): 1-10. Print.

Davis, Gregson. “'Homecomings without Home': Representations of (Post)Colonial Nostos (Homecoming) in the Lyric of Aimé Césaire and Derek Walcott." Homer in the Twentieth Century: Between World Literature and the Western Canon. Ed. Barbara Grazisoi and Emily Greenwood: Oxford University Press, 2007. 191-209. Print.

Fanon, Frantz. The Wretched of the Earth. Trans. Constance Farrington: New York: Grove Press, 1963. Print. 
Southeast Asian Review of English, 52.1(2014/2015): 143-166.

Figueroa, Víctor. Not at Home in One's Home: Caribbean Self-Fashioning in the Poetry of Luis Palés Matos, Aimé Césaire, and Derek Walcott. Associated University Presse, 2009. Print.

François, Anne M. Rewriting the Return of Africa: Voices of Francophone Caribbean Women Writers. Lexington Books, 2011. Print.

Freud, Sigmund. "The Uncanny (1919).” Trans. from the German under the general editorship of James Strachey in collaboration with Anna Tyson, assisted by Alix Strachey and Alan Tyson. The Standard Edition of the Complete Psychological Works of Sigmund Freud London: Hogarth Press, 1964. 217-56. Print.

Friedman, Rachel D. "Derek Walcott's Odysseys." International Journal of the Classical Tradition 14.3/4 (2007): 455-80. Print.

Glissant, Édouard. Poetics of Relation. Trans. Betsy Wing: University of Michigan Press, 1997. Print.

---. Caribbean Discourse: Selected Essays. Trans. J. Michael Dash: Charlottesville: U of Virginia P, 1989. Print.

Graham, Shane. “'I Had Forgotten a Continent': Cosmopolitan Memory in Derek Walcott's Omeros." Traversing Transnationalism: The Horizons of Literary and Cultural Studies. Eds. Frassinelli, Pier Paolo, Ronit Frenkel and David Watson. Vol. 62: Rodopi, 2011. 95118. Print.

Hall, Edith, and Justine McConnell. "Mythopoeia in the Struggle against Slavery, Racism, and Exclusive Afrocentrism." African Athena: New Agendas. Eds. Daniel Orrells, Gurminder K Bhambra and Tessa Roynon: Oxford University Press, 2011. 343-61. Print. 
Southeast Asian Review of English, 52.1(2014/2015): 143-166.

Hall, Stuart. "Cultural Identity and Diaspora". Identity: Community, Culture, Difference. Ed. Janathan Rutherford: Lawrence \& Wishart, 1990. 222-37. Print.

Hamner, Robert D. Epic of the Dispossessed: Derek Walcott's Omeros. Columbia: University of Missouri Press, 1997. Print.

Handley, George B. “'The Argument of the Outboard Motor.' Caribbean Literature and the Environment: Between Nature and Culture. Ed. Elizabeth M. Deloughrey, Renée K. Gosson, and George B. Handley: Charlottesville: University of Virginia Press, 2005. 12739. Print.

Hardwick, Lorna. "Classical Texts in Post-Colonial Literatures: Consolation, Redress and New Beginnings in the Work of Derek Walcott and Seamus Heaney.” International Journal of the Classical Tradition 9.2 (2002): 236-56. Print.

---. Translating Words, Translating Cultures. Duckworth, 2004. Print.

---. "Walcott's Philoctete: Imagining the Post-Colonial Condition." Translating Words, Translating Cultures. Duckworth, 2004. 97-112. Print.

Hofmeister, Timothy P. "The Wolf and the Hare: Epic Expansion and Contextualization in Derek Walcott's 'Omeros'.” International Journal of the Classical Tradition 2.4 (1996): 536-54. Print.

King, Bruce. Derek Walcott: A Caribbean Life. Oxford University Press, 2000. Print. McConnell, Justine. Black Odysseys: The Homeric Odyssey in the African Diaspora since 1939. Oxford University Press, 2013. Print.

McCorkle, James. "Re-Mapping the New World: The Recent Poetry of Derek Walcott." ARIEL: A Review of International English Literature 17.2 (1986). Print. 
Southeast Asian Review of English, 52.1(2014/2015): 143-166.

Melas, Natalie. "Forgettable Vacations and Metaphor in Ruins: Walcott's 'Omeros'." Callaloo 28.1 (2005): 147-68. Print.

Rodman, Selden. Tongues of Fallen Angels: Conversations with Jorge Luis Borges Et Al. New York: New Directions Books, 1974. Print.

Sickle, John B. Van. "The Design of Derek Walcott's 'Omeros'." The Classical World 93.1 (1999): 7-27. Print.

Soyinka, Wole. "Realms of Value in Literature Art: Interview with Wole Soyinka." Conversations with Wole Soyinka. Ed. Biodun Jeyifo: University Press of Mississippi, 2001. 116-28. Print.

Strachan, Ian G. . "Walcott's Postcolonial Adam." Paradise and Plantation: Tourism and Culture in the Anglophone Caribbean. University of Virginia Press, 2003. 192-223. Print.

Terada, Rei. Derek Walcott's Poetry: American Mimicry. Northeastern University Press Boston, 1992. Print.

Thomas, Bonnie. "Edouard Glissant and the Art of Memory." Small Axe 13.330 (2009): 25-36. Print.

Tynan, Maeve. Postcolonial Odysseys: Derek Walcott's Voyages of Homecoming. Cambridge Scholars Publishing, 2011. Print.

Walcott, Derek. “The Antilles, Fragments of Epic Memory: The 1992 Nobel Lecture." World Literature Today 67.2 (1993): 261-67. Print.

---. Dream on Monkey Mountain and Other Plays. Farrar, Straus and Giroux, 1971. Print.

---. "Necessity of Négritude." Critical Perspectives on Derek Walcott. Ed. Robert D. Hamner: Washington, DC: Three Continents Press, 1993. 20-23. Print.

---. The Odyssey: A Stage Version. Farrar, Straus and Giroux, 1993. Print. 
Southeast Asian Review of English, 52.1(2014/2015): 143-166.

---. Omeros. New York: Farrar, Straus and Giroux, 1990. Print.

---. “Reflections on ‘Omeros'.” South Atlantic Quarterly 96.2 (1997): 229-46. Print.

---. “'The Schooner Flight.' The Poetry of Derek Walcott 1948-2013. Ed. Glyn Maxwell: New York: Farrar, 2014. 237-53. Print.

---. What the Twilight Says: Essays. Faber \& Faber, 1998. Print.

Zoppi, Isabella Maria. “'Omeros', Derek Walcott and the Contemporary Epic Poem.” Callaloo 22.2 (1999): 509-28. Print. 
Southeast Asian Review of English, 52.1(2014/2015): 143-166.

\section{Notes}

${ }^{1}$ This paper is drawn from my doctoral thesis.

${ }^{2}$ Glissant like other Caribbean intellectuals does not advocate the monolithic ideologies of this raced-based movement as he believes Afro-descent people are not African anymore and their return "is already too late" (Caribbean Discourse 17). Soyinka even goes so far as to call the advocates of Négritude "neo-Tarzanists" (123).

${ }^{3}$ Regarding Walcott's concern with Négritude see his essay "What the Twilight Says"; Rei Terada, Derek Walcott's Poetry: American Mimicry pp. 26-8; Victor Figueroa, Not at Home in One's Home 163; Justine McConnell, Black Odysseys: The Homeric Odyssey in the African Diaspora since 1939, pp. 42-4; Derek Walcott, "Necessity of Négritude” pp. 20-23.

${ }^{4}$ On Walcott's denunciation of tourism industry see "The Antilles, Fragments of Epic Memory: The 1992 Nobel Lecture"; George B. Handley's interview with Walcott, "The Argument of the Outdoor Motor': An Interview with Derek Walcott" pp.127-39; Paula Burnett, Derek Walcott: Politics and Poetics pp. 53-3; Ian G. Strachan, Paradise and plantation: Tourism and culture in the Anglophone Caribbean; on tourism in Omeros see Natalie Melas, "Forgettable Vacations and Metaphor in Ruins: Walcott's 'Omeros",; Anthony Carrigan, "Postcolonial Tourism, Island Specificity, and Literary Representation: Observations on Derek Walcott's Omeros"; on ecotourism in the Caribbean within the arc of Kincaid's A Small Place, Walcott's Omeros and Glissant's Poetics of Relation (in particular the essays on 'The Burning Beach' and 'Distancing, Determining') see Jana Evans Braziel, "Caribbean Genesis in Caribbean Literature and the Environment (Jamaica Kincaid, Derek Walcott, Édouard Glissant)” pp.110-26.

${ }^{5}$ Robert D. Hamner relates Achille's wrath to Homer's Achilles who did not back Troy's siege after losing Briseis and stayed in his tent (67).

${ }^{6}$ For McConnell, this African journey recalls “"Back to Africa' campaigns" which Garvey revived in the 1920s while it existed from the beginning of the nineteenth century (Black Odysseys: The Homeric Odyssey in the African Diaspora since 1939, pp. 119-20).

7 Gregson Davis, “Homecomings without Home': Representations of (Post)Colonial Nostos (Homecoming) in the Lyric of Aimé Césaire and Derek Walcott" 195; Lorna Hardwick, "Walcott's Philoctete: Imagining the Post-Colonial Condition" pp. 105-6; Rachel D. Friedman, "Derek Walcott's Odysseys" 459.

${ }^{8}$ Rei Terada, Derek Walcott's Poetry: American Mimicry 203; Peter Burian, “'All That Greek Manure under the Green Bananas': Derek Walcott's' Odyssey" 368. Burian takes Achille as Odysseus and his dream voyage as "his nostos, his return home; at the same time [Achille] is Telemachus in search of his father; both aspects are explicit in Omeros" (368).

9 Achille's descent to the underworld is like Odysseus' katabasis in Book XI of Homer's Odyssey and the Virgilian Aeneas' descent in Book VIII in the Aeneid "in which Aeneas in fact journeys up the Tiber to visit Evander and finds a model Greek colony in which he is told about justifications for conquest" (Hardwick, "Classical Texts in Post-Colonial Literatures: Consolation, Redress and New Beginnings in the Work of Derek Walcott and Seamus Heaney" 242). 
${ }^{10}$ For discussion of memory/postmemory as a postcolonial concept with particular reference to Glissant's contribution refer to Bonnie Thomas "Édouard Glissant and the Art of Memory."

${ }^{11}$ In composing Omeros, Walcott not only borrows the terza rima verse form from Dante's Divine Comedy "but also the half-detached authorial voice, standing back from the action but engaged with it" (Hardwick, Translating Words, Translating Cultures 106). This is one of the reasons that Walcott believes Omeros is not an epic as the author is a character in the narrative. On denunciation of epic status of Omeros see Bruce King, Derek Walcott: A Caribbean Life 519.

${ }^{12}$ For discussion of Achille's physic and his vulnerable heel see Isabella M. Zoppi, “'Omeros', Derek Walcott and the Contemporary Epic Poem" pp. 517-18; John B.V. Sickle, "The Design of Derek Walcott's 'Omeros'” 24.

${ }^{13}$ Timothy P. Hofmeister has related the violence of this scene to the violence Achille's mate uses to catch the albacore, a great fish that lies besides Achille in the belly of Achille's canoe. See "The Wolf and the Hare: Epic Expansion and Contextualization in Derek Walcott's 'Omeros" " pp. 550-51.

${ }^{14}$ On this festival see Shane Graham, “'I Had Forgotten a Continent': Cosmopolitan Memory in Derek Walcott's Omeros" pp. 115-16; Justine McConnell, Black Odysseys: The Homeric Odyssey in the African Diaspora since 1939, 131. 